JURNAL SELAT

Volume. 8 Nomor. 2, Mei 2021. p - 2354-8649 I e - 2579-5767

Open Access at: http://ojs.umrah.ac.id/index.php/selat

DOI: https://doi.org/10.31629/selat.v8i2.3387

\title{
TANGGUNG GUGAT ATAS JUAL BELI PULAU LANTIGIANG BERDASARKAN SYARAT SAH NYA PERJANJIAN
}

\author{
Arum Prabaning Tyas \\ Magister Kenotariatan Fakultas Hukum Universitas Surabaya \\ Jalan Raya Kalirungkut, Surabaya 60293 \\ arumprabaning@gmail.com
}

\begin{abstract}
Lantigiang Island, uninhabited island covering an area of 5.6 hectares located in Jinato Village, Takabonerate District, Selayar Islands Regency, South Sulawesi. This island is reported to have been sold by Syamsul Alam, who claims to be the owner of the island, to Asdianti, a resident of the Selayar island for Rp. 900,000,000 (Nine Hundred Million Rupiah). Lantigiang Island is included in the Takabonerate National Park area and is a protected conservation area. The conservation area aims to conserve the forest and the life in it, including the diversity of plants and animals and their ecosystems so that their functions can be carried out optimally. According to the agrarian regime, conservation areas are not for sale in general. This writing is compiled through a normative juridical analysis method with a statue approach, a conceptual approach and a case approach. Based on these three methods, it is necessary to observe and analyze which party is most responsible for the buying and selling process of the island of Lantigiang.
\end{abstract}

Keywords; Island Trading, Conservation Area, Responsibility.

\begin{abstract}
Abstrak
Pulau Lantigiang, sebuah pulau tak berpenghuni seluas 5,6 hektar yang secara adminstratif terletak di Desa Jinato, Kecamatan Takabonerate, Kabupaten Kepulauan Selayar, Sulawesi Selatan. Pulau ini dikabarkan telah dijual oleh Syamsul Alam yang mengaku sebagai pemilik pulau kepada Asdianti, seorang warga kepulauan Selayar sebesar Rp.900.000.000,- (Sembilan Ratus Juta Rupiah). Pulau Lantigiang termasuk dalam kawasan Taman Nasional Takabonerate dan merupakan wilayah konservasi yang dilindungi. Wilayah konservasi memiliki tujuan untuk melestarikan hutan dan kehidupan yang ada didalamnya termasuk keanekaragaman tumbuhan dan satwa berikut ekosistemnya agar fungsinya bisa dijalankan secara maksimal. Menurut rezim agraria, wilayah konservasi tidak untuk diperjual belikan secara umum. Penulisan ini disusun melalui metode analisa yuridis normatif dengan pendekatan peraturan perundang-undangan (statue approach), pendekatan konseptual (conceptual approach) dan pendekatan kasus (case approach). Berdasarkan ketiga metode tersebut perlu dicermati dan dianalisa mengenai pihak mana yang paling bertanggungjawab atas terjadinya proses jual beli pulau Lantigiang.
\end{abstract}

Kata kunci; Jual Beli Pulau, Wilayah Konservasi, Tanggung Jawab. 


\section{PENDAHULUAN}

Indonesia adalah negara kepulauan dengan jumlah pulau sampai dengan tahun 2020 adalah 16.671 berdasarkan data resmi yang sudah dilaporkan dan didaftarkan ke PBB. ${ }^{1}$ Luas lautan dan daratan Indonesia seluruhnya $5.193 .250 \mathrm{~km}^{2}$ dengan rincian luas daratan $1.919 .440 \mathrm{~km}^{2}$ dan luas lautannya $3.273 .810 \mathrm{~km}^{2}$ (berdasarkan Sumber Belajar Kementerian Pendidikan Kemdikbud). Sebagai salah satu negara dengan luas lautan yang besar, terdapat pulau-pulau sebagai daratan yang tersebar di seluruh wilayah Indonesia. Pulau-pulau besar yang ada di Indonesia antara lain : Pulau Jawa, Sumatra, Kalimantan, Sulawesi dan Papua yang disebut juga sebagai 5 (lima) pulau besar utama, sedangkan pulau-pulau kecil yang tersebar di wilayah Indonesia jumlahnya ribuan baik yang sudah bernama maupun yang belum bernama, dan yang dihuni maupun pulau-pulau tak berpenghuni (pulau kosong). Data dari BPS yang dirilis tahun 2017 menyebutkan jumlah pulau di Indonesia baik yang besar maupun yang kecil sebanyak 16 (enam belas) ribu. Propinsi Kepulauan Riau memiliki pulau terbanyak sebesar 2.408 pulau, kemudian Papua Barat dengan 1.945 pulau dan Maluku Utara dengan 1.474 pulau. Sementara propinsi yang paling sedikit memiliki pulau adalah Daerah Istimewa Yogyakarta dengan 19 pulau serta Jambi 19 pulau. $^{2}$

Grafik 1. Jumlah Pulau berdasarkan Propinsi di Indonesia

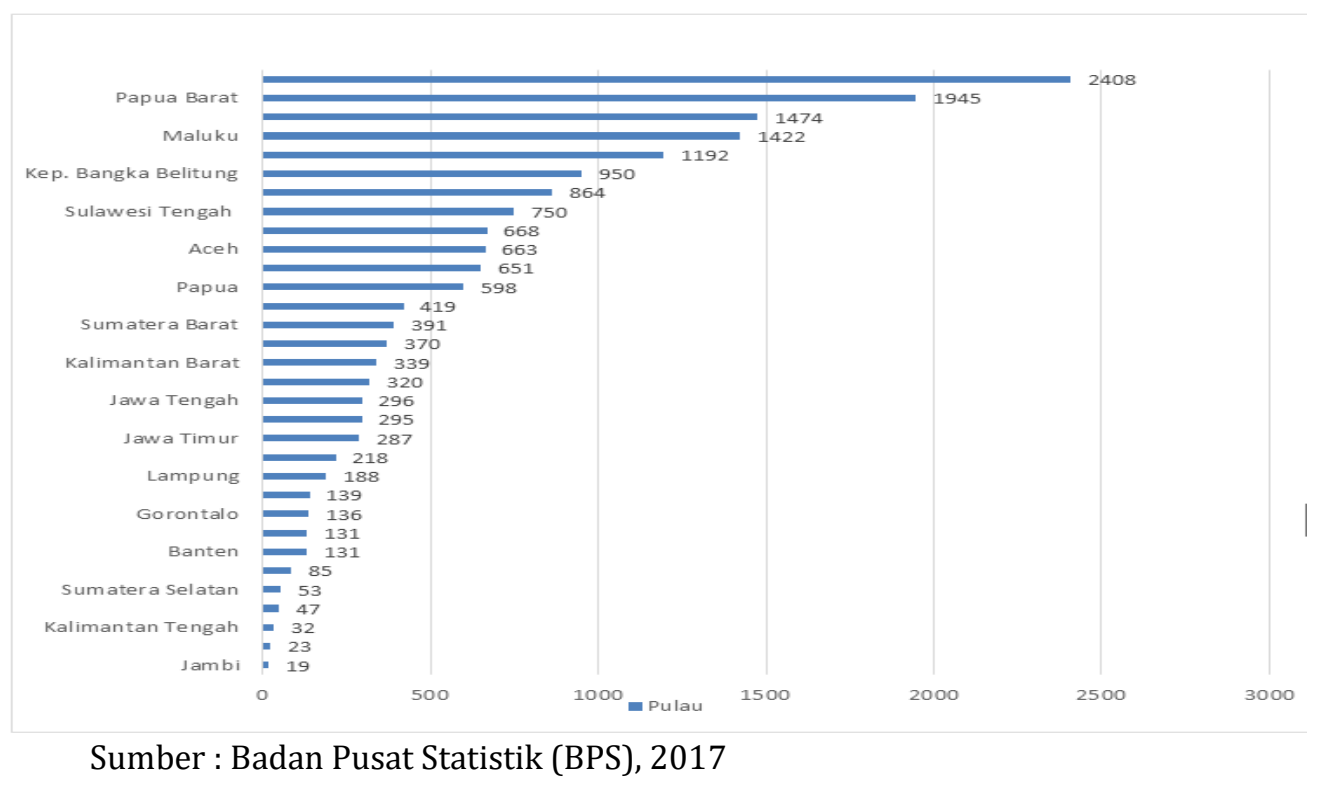

\footnotetext{
1 https://ditjenbinaadwil.kemendagri.go.id/index.php/2020/09/01/koordinasi-penyamaan-persepsi-jumlahpulau-di-indonesia-tahun-2020/ diakses 16 Maret 2021

2 https://databoks.katadata.co.id/datapublish/2016/ diakses 16 Maret 2021
} 
Pulau Lantigiang adalah sebuah pulau tak berpenghuni seluas 5,6 hektar yang terletak di Kabupaten Kepulauan Selayar Propinsi Sulawesi Selatan. Pulau tersebut telah dijual oleh salah satu warga desa Jampea, Kabupaten Kepulauan Selayar yang bersama Syamsul Alam sebesar 900 Juta kepada Asdianti, seorang warga desa Laiyolo, Kecamatan Bontosikuyu, Kabupaten Kepulauan Selayar. Dasar kepemilikan tanah di pulau Lantigiang menurut Syamsul Alam adalah secara turun temurun nenek moyangnya telah menanam pohon kelapa di tanah pulau tersebut. Proses jual beli Pulau Lantigiang, diberikan uang panjar (tanda jadi) sebesar 10 Juta Rupiah dari pembeli pulau tersebut dan telah terbit Surat Keterangan atas Jual Beli Pulau Lantigiang. ${ }^{3}$ Menurut Asdianti, tujuan membeli Pulau Lantigiang adalah untuk pengembangan kawasan wisata bahari dan berencana akan membangun resort di kawasan tersebut. Berdasarkan SK Menteri Kehutanan Nomor 92/KPTS-II/2001 tanggal 15 Maret 2001, Pulau Lantigiang sebagai kawasan ekosistem bahari termasuk dalam kawasan Taman Nasional (TN) Takabonerate yang merupakan wilayah konservasi untuk melestarikan hutan dan kehidupan yang ada didalamnya termasuk keanekaragaman tumbuhan dan satwa berikut ekosistemnya agar fungsinya bisa dijalankan secara maksimal. Secara geografis, TN Takabonerate terletak di Laut Flores yng memiliki karang atoll terbesar ketiga dunia dengan luas mencapai 220.000 hektar serta memiliki keanekaragaman biota laut yang tinggi dan habitat bagi berbagai spesies satwa laut yang langka dan dilindungi. ${ }^{4}$

Berdasarkan Surat Keputusan dari Dirjen Konservasi Sumber Daya Alam dan Ekosistem KLHK yang terbit pada Januari 2019, Pulau Lantigiang tidak dapat dimiliki secara perorangan karena merupakan kawasan zona pemanfaatan perlindungan bahari. Sebagai wilayah yang termasuk kawasan zona pemanfaatan, Pulau Lantigiang termasuk dalam kawasan ekosistem bahari dan sebagai tempat untuk penangkaran satwa-satwa yang hampir punah seperti penyu serta kawasan perlindungan biota laut serta keaneka ragaman hayati lainnya. Apabila dilihat dari kondisi serta kekayaan sumber daya alam, maka wilayah tersebut dapat dimanfaatkan sebagai kawasan pariwisata alam. Pulau Lantigiang dan sekitarnya yang kaya akan sumber daya alam dan biota laut dapat memenuhi kehidupan para nelayan di wilayah

\footnotetext{
3 https://www.liputan6.com/regional/read/4472400/klaim-sebagai-peninggalan-nenek-moyangnya-wargaselayar-jual-pulau-lantigiang-seharga-rp900-juta diakses tanggal 18 Maret 2021

${ }^{4}$ https://id.wikipedia.org/wiki/Taman_Nasional_Taka_Bonerate diakses tanggal 19 Maret 2021
} 
tersebut. Sehingga sampai dengan saat ini kawasan konservasi tersebut berubah menjadi kawasan pemukiman warga setempat yang berprofesi sebagai nelayan. Hal ini tentu bertentangan dengan Keputusan dari Dirjen Konservasi Sumber Daya Alam dan Ekosistem KLHK yang menetapkan wilayah Pulau Lantigiang dan sekitarnya sebagai kawasan zona pemanfaatan perlindungan bahari.

Proses jual beli pulau lantigiang yang termasuk kawasan zona pemanfaatan perlindungan bahari perlu kembali ditinjau ulang. Syarat-syarat jual beli menurut pasal 1320 KUH Perdata, ada 4 (empat) syarat yang harus dipenuhi antara lain : Pertama, Adanya kata sepakat bagi mereka yang mengikatkan dirinya; Kedua, Kecakapan para pihak untuk membuat suatu perikatan; Ketiga, Suatu hal tertentu; dan Keempat, Suatu sebab (causa) yang halal. Menurut Retna Gumanti dalam penelitiannya mengenai Syarat Sahnya Perjanjian Ditinjau dari KUH Perdata, menyatakan apabila unsur sepakat dari para pihak dan kecakapan untuk melakuan perikatan tidak dapat dipenuhi maka perjanjian jual beli tersebut dapat dibatalkan karena tidak memenuhi syarat subyektif yang berkenaan dengan subyek perjanjian. Sedangkan unsur hal tertentu dan sebab yang halal merupakan unsur obyektif dari sebuah perjanjian, oleh karena itu apabila tidak terpenuhi maka perjanjian tersebut dianggap tidak pernah ada atau batal demi hukum. ${ }^{5}$ Klausul batal demi hukum dijelaskan lebih rinci oleh Nanin Koeswidi Astuti dalam artikel yang berjudul Analisa Yuridis tentang Perjanjian Dinyatakan Batal Demi Hukum. Perjanjian tersebut dianggap tidak pernah lahir, dan tidak pernah terjadi apabila tidak terpenuhinya syarat obyektif. Secara hukum belum pernah ada kesepakatan atau kesepakatan hukum, sehingga karena tidak ada dasar hukumnya, tidak mungkin menggugat pihak manapun untuk mencapai kesepakatan di pengadilan. ${ }^{6}$

Berdasarkan problematika yang diuraikan diatas, maka rumusan masalah dalam penelitian ini adalah apakah suatu wilayah yang menjadi kawasan konservasi Taman Nasional dapat secara bebas diperjual belikan? Siapakah yang dapat dimintai pertanggung jawaban terkait jual beli pulau tersebut?.

\footnotetext{
${ }^{5}$ Retna Gumanti, Syarat Sahnya Perjanjian (Ditinjau dari KUHPerdata), Jurnal Pelangi Ilmu, Volume 5 No. 01, http://ejurnal.ung.ac.id/index.php/JPI/article/view/900/840\#, 2012

${ }^{6}$ Nanin Koeswidi Astuti, Analisa Yuridis tentang Perjanjian Dinyatakan Batal Demi Hukum, Jurnal Hukum to-ra, Volume 2 No. 1, http://ejournal.uki.ac.id/index.php/tora/article/view/1130/958, April 2016
} 


\section{METODE PENELITIAN}

Penelitian ini adalah Penelitian Hukum. Soerjono Sukanto meyakini bahwa penelitian hukum adalah suatu peristiwa yang lahir secara ilmiah, berdasarkan metode, sistem, dan pemikiran tertentu, serta bertujuan untuk menganalisis dan mengkaji fenomena hukum tertentu. Oleh karena itu studi mendalam terhadap fakta hukum dilakukan untuk mengatasi permasalahan di gejala tersebut. ${ }^{7}$ Peter Mahmud Marzuki merumuskan penelitian hukum sebagai proses mewujudkan aturan hukum, asas hukum dan doktrin hukum sehingga pertanyaan hukum dapat terjawab untuk memperoleh data yang diperlukan dari objek penelitian. ${ }^{8}$

Dalam penelitian ini, pendekatan yang digunakan adalah pendekatan peraturan perundang-undangan (statue approach), pendekatan konseptual (conceptual approach) dan pendekatan kasus (case approach). Pendekatan peraturan perundangundangan (statue approach) dilakukan untuk memeriksa produk hukum yang digunakan sebagai referensi terkait penelitian. Bahan hukum utama adalah peraturan perundang-undangan yang terkait dengan masalah yang sedang terjadi. Pendekatan ini dilakukan untuk mengkaji/meneliti peraturan perundang-undangan yang satu apakah relevan atau tidak dengan peraturan yang lainnya. Pendekatan Konseptual (conceptual approach) bersumber dari sudut pandang dan doktrin hukum sehingga akan mengembangkan dan menumbuhkan asas hukum yang baru dan relevan. ${ }^{9}$ Pendekatan Kasus (case approach) memiliki tujuan untuk menemukan cara terbaik dalam menangani peristiwa hukum yang terjadi. Mengupayakan nilai kebenaran dan solusi terbaik atas peristiwa hukum yang terjadi sesuai dengan prinsip keadilan. Metode ini dilakukan dengan menganalisis kasus-kasus yang berkaitan dengan masalah hukum. Kasus yang sedang dikaji adalah kasus yang terjadi di masyarakat, sehingga akan dicari penyelesaian berdasarkan asas keadilan dan dapat dijadikan dasar untuk menyelesaikan masalah hukum yang dihadapi.

\section{PEMBAHASAN}

\subsection{Keabsahan Jual Beli Terkait Wilayah Konservasi}

\footnotetext{
${ }^{7}$ Soerjono Soekanto, Pengantar Penelitian Hukum Indonesia, Universitas Indonesia, Jakarta, 1986, hal. 42.

8 Peter Mahmud Marzuki, Penelitian Hukum (Edisi Revisi), Kencana, Jakarta, 2017, hal. 93

${ }^{9}$ Ibid
} 
Perjanjian jual beli sebagaimana didefinisikan dalam Pasal 1313 KUH Perdata yaitu: "Perjanjian adalah tindakan di mana satu atau lebih orang mengikatkan diri pada satu atau lebih orang lain". Menurut pasal ini, perjanjian hanya menimbulkan kewajiban-kewajiban bagi para pihak yang melakukan perjanjian atau yang disebut dengan perjanjian obligatoir. Hubungan antara penjual dan pembeli merupakan hubungan timbal balik dimana penjual menyerahkan barangnya kepada pembeli dan pembeli membayar atas barang tersebut. Menurut Prof. Subekti, perjanjian adalah peristiwa dimana seorang berjanji kepada orang lain atau di mana dua orang itu saling berjanji untuk melaksanakan sesuatu hal. ${ }^{10}$ Menurut Sudikno Mertokusumo, perjanjian adalah hubungan hukum yang berdasarkan kesepakatan yang menimbulkan akibat hukum. Terjadinya hubungan hukum antara subjek hukum yang satu dengan subjek hukum yang lain dimana salah satu subjek hukum berhak atas prestasi sedangkan subjek hukum lainnya juga berkewajiban untuk melaksanakan prestasinya sesuai dengan kesepakatan keduanya. ${ }^{11}$

Perjanjian terdiri dari subyek hukum dan obyek hukum. Subyek hukum dari suatu perjanjian adalah manusia dan badan hukum. Sedangkan obyek hukum perjanjian adalah suatu barang, terdapat klasifikasi barang yang tercantum dalam KUH Perdata antara lain : barang yang dapat diperdagangkan (Pasal 1332 KUH Perdata), barang yang dapat ditentukan jenisnya (Pasal 1333 KUH Perdata), barangbarang yang akan ada dikemudian hari (Pasal 1334 ayat (2) KUH Perdata). Berkaitan dengan jual beli tanah pulau yang terjadi pada Pulau Lantigiang, merupakan perjanjian antara penjual dan pembeli perseorangan sebagai subyek hukumnya. Obyek dari perjanjian ini adalah suatu tanah yang terletak di sebuah pulau bernama lantigiang. Tanah dalam hukum pertanahan secara yuridis memiliki arti permukaan bumi, sebagaimana tertuang dalam Pasal 4 UUPA (yang menjelaskan penguasaan negara atas tanah), ditentukan adanya macam-macam hak atas permukaan bumi yang disebut tanah. ${ }^{12}$ Penguasaan atas tanah kemudian dijelaskan secara rinci dalam pasal 16 ayat (1) UUPA mengenai hak-hak atas tanah adalah sebagai berikut :

a. Hak Milik;

10 Much. Nurachmad, Buku Pintar Memahami dan Membuat Surat Perjanjian, Transmedia Pustaka, Jakarta, 2010, hal. 5

11 Sudikno Mertokusumo, Ilmu Hukum, Penerbit Liberty, Yogyakarta, 2008, hal. 21

12 Boedi Harsono, Sejarah Pembentukan Undang-undang pokok Agraria, Isi dan Pelaksanaannya, Djambatan, Jakarta, 1999, hal. 37 
b. Hak Guna Usaha;

c. Hak Guna Bangunan;

d. Hak Pakai;

e. Hak Sewa untuk Bangunan;

f. Hak Membuka Tanah;

g. Hak Memungut Hasil Hutan;

h. Hak-hak lain yang tidak termasuk dalam hak-hak tersebut diatas tanah yang akan ditetapkan dengan undang-undang.

Hak atas tanah sebagaimana tercantum dalam Pasal 1 ayat (4) Peraturan Pemerintah No. 18 tahun 2021 (PP 18/2021) tentang Hak Pengelolaan, Hak Atas Tanah, Satuan Rumah Susun, dan Pendaftaran Tanah, memberikan pengertian yaitu : hak yang diperoleh dari hubungan hukum antara pemegang hak dengan tanah, termasuk ruang di atas tanah, dan atau ruang di bawah tanah untuk menguasai, memiliki, menggunakan, dan memanfaatkan, serta memelihara tanah, ruang di atas tanah, dan/atau ruang di bawah tanah. Perolehan hak atas tanah dapat dilakukan dengan cara sebagai berikut $:^{13}$

1. Hak atas tanah yang diperoleh secara original. Yaitu hak yang dimilki pertama kalinya oleh seseorang ataupun badan hukum. Macam hak atas tanah ini antara lain :

a) Hak milik, hak guna usaha, hak guna bangunan, hak pakai diatas tanah Negara;

b) Hak milik, hak guna bangunan, hak pakai yang berasal dari hak pengelolaan;

c) Hak guna bangunan yang diperoleh dari perbahn hak milik;

d) Hak milik yang berasal dari hukum adat;

e) Hak milik yang terjadi diatas tanah hukum adat.

2. Hak atas tanah yang diperoleh secara derivatif. Yaitu hak turunan dari seseorang maupun badan hukum dari hak atas tanah yang dimiliki atau dikuasai pihak lain. Macam hak atas tanah ini antara lain :

a) Seseorang atau badan hukum yang membeli tanah milik pihak lain;

13 Urip Santoso, Pendaftaran dan Peralihan Hak Atas Tanah, Kencana Prenada Media, Jakarta, 2009, hal. 52 
b) Seseorang atau badan hukum yang mendapatkan hibah tanah dari pihak lain;

c) Seseorang atau badan hukum yang melakukan tukar-menukar tanah dengan pihak lain;

d) Seseorang atau badan hukum yang mendapatkan warisan berupa tanah dari orang tuanya;

e) Seseorang atau badan hukum yang mendapatkan hak atas tanah melalui proses lelang.

Ketentuan kepemilikan pulau, harus mengutamakan penerapan prinsip konservasi yang menyeluruh dan berkelanjutan. Pulau adalah sebidang tanah, dan kepemilikan atau pengaturan pengalihannya tunduk pada UUPA. Disamping itu, Undang-undang No. 27 Tahun 2007 sebagaimana telah diubah oleh Undang-Undang No. 1 Tahun 2014 tentang pengelolaan wilayah pesisir dan pulau-pulau kecil menetapkan bahwa karena wilayah pulau kecil ini sangat terbatas, dan keberadaannya merupakan kesatuan ekosistem pesisir dan laut, maka karakteristik pulau kecil tersebut jangan hanya dianggap sebagai bidang-bidang tanah saja. Oleh karena itu untuk pulau-pulau kecil hanya boleh dimanfaatkan pertama untuk kepentingan riset, pendidikan, dan wisata bahari.

Tanah sebagai obyek hukum dalam jual beli pulau lantigiang, tidak memenuhi syarat obyektif sebagaimana yang tercantum dalam Pasal 1320 KUH Perdata, yaitu mengenai causa (obyek) yang halal karena tanah yang dijadikan obyek jual beli termasuk dalam wilayah konservasi TN Takabonerate. Wilayah konservasi dalam arti sebagai kawasan pelestarian alam berdasarkan Undang-Undang Nomor 5 Tahun 1990 tentang Konservasi Sumber Daya Alam Hayati dan Ekosistemnya pada Pasal 1 angka 2 disebutkan pengertian konservasi sumber daya alam hayati adalah pengelolaan sumber daya alam hayati yang pemanfaatannya dilakukan secara bijaksana untuk menjamin kesinambungan persediaannya dengan tetap memelihara dan meningkatkan kualitas keanekaragaman dan nilainya.

Oleh sebab itu tanah pulau lantigiang yang termasuk dalam wilayah zona konservasi harus dilindungi. Peruntukannya harus sesuai dengan rencana tata ruang wilayah provinsi/kabupaten/kota, atau rencana zonasi pulau dengan tetap mengutamakan kepentingan Nasional antara lain : pertahanan dan keamanan; 
kedaulatan negara; pertumbuhan ekonomi; sosial dan budaya; fungsi dan daya dukung lingkungan hidup; pelestarian warisan dunia; dan/atau program strategis nasional.

\subsection{Pertanggungjawaban jual beli pulau yang termasuk Kawasan Konservasi}

Taman Nasional Takabonerate yang memiliki arti taka : karang, bone : pasir, rate : atas (Hamparan Karang diatas Pasir) semula adalah kawasan cagar alam sejak tahun 1989. Pada tahun 1992 statusnya berubah menjadi Taman Nasional dengan luas 530.765 Ha (hektar). Sejak tahun 2002 kawasan ini menjadi Balai Taman Nasional berdasarkan SK Menhut No. 6186/Kpts-II/2002 tentang Organisasi dan Tata Kerja Balai Taman Nasional. ${ }^{14}$ Pengelolaan kawasan Taman Nasional Takabonerate dilakukan melalui pembagian zona. Kriteria zona dalam Taman Nasional Takabonerate berdasarkan Keputusan Direktorat Jenderal PHKA Nomor : SK. 150/IV-SET/2012 tanggal 17 September 2012 tentang Zonasi Taman Nasional Taka Bonerate terdiri dari 4 zona yaitu Zona Inti (8.341 Ha), Zona Perlindungan Bahari (21.188 Ha), Zona Pemanfaatan (500.879 Ha) dan Zona Khusus (357 Ha). Kemudian berdasarkan Surat Keputusan Direktorat Jenderal Konservasi Sumber Daya Alam dan Ekosistem Nomor : SK.23/KSDAE/SET/KSA.0/1/2019, Tanggal 23 Januari 2019 dilakukan review terhadap pembagian zona yang terdiri dari 7 zona yaitu Zona Inti (10.046 Ha), Zona Perlindungan Bahari (25.875 Ha), Zona Pemanfaatan (9.491 Ha) dan Zona Khusus (270 Ha), Zona Tradisional (481.334 Ha), Zona Religi, Budaya dan Sejarah (3.279 Ha) dan Zona Rehabilitasi (472 Ha). ${ }^{15}$

Berdasarkan Surat Keputusan dari Dirjen Konservasi Sumber Daya Alam dan Ekosistem KLHK yang terbit pada Januari 2019, Pulau Lantigiang dan perairan di sekitarnya seluas 2854,80 Ha termasuk dalam kriteria zona kemanfaatan. Beberapa kriteria yang termasuk dalam zona pemanfaatan antara lain :

a. merupakan wilayah yang memiliki keindahan alam/daya tarik alam atau nilai sejarah dan/atau wilayah dengan aksesibilitas yang mampu mendukung aktivitas pemanfaatan;

\footnotetext{
14 https://tntakabonerate.com/id/sejarah-2/ diakses tanggal 20 Maret 2021

15 Ibid
} 
b. merupakan wilayah yang memungkinkan dibangunnya sarana prasarana antara lain untuk menunjang pemanfaatan dan pengelolaan;

c. bukan merupakan konsentrasi komunitas tumbuhan/biota utama;

d. bukan merupakan areal dengan keragaman jenis yang tinggi; dan/atau

e. terdapat potensi jasa lingkungan yang dapat dimanfaatkan. ${ }^{16}$

Kawasan Konservasi di Indonesia merupakan suatu kawasan yang dilindungi. Konsep dari konservasi adalah melindungi dan mengindari dari kerusakan suatu habitat/tempat hidupnya beragam mahkluk hidup baik berupa tumbuhan, satwa dan ekosistemnya dari kerusakan karena erosi, longsor dan kepunahan. Undang-Undang Dasar 1945 pasal 33 ayat (2) menjelaskan mengenai segala kekayaan alam termasuk bumi dan perairan dikuasai oleh Negara. Ini memberikan pengertian bahwa negara memiliki hak untuk menguasai tanah-tanah yang termasuk dalam wilayah Negara Indonesia. Hak menguasai negara menurut pasal 2 Ayat (2) UUPA adalah negara diberikan kewenangan untuk bertindak secara aktif maupun pasif dalam bidang pemerintahan negara. Wewenang negara tidak hanya berkaitan dengan wewenang pemerintahan semata, tetapi meliputi pula wewenang dalam rangka melaksanakan tugasnya sebagai penguasa dan pemegang kekuasaan tertinggi. ${ }^{17}$ Wujud dari pelaksanaan kewenangan negara dalam hal menjaga wilayahnya adalah dengan mengatur regulasi terkait ijin yang diberikan dalam hal pengelolaan tanah di wilayah pulau-pulau kecil utamanya wilayah yang termasuk dalam kawasan konservasi. Pengelolaan kawasan konsevasi harus mendapatkan ijin pemanfaaatan pulau sebagaimana tercantum dalam Undang-Undang No. 1 tahun 2014 tentang Perubahan atas Undang-Undang Nomor 27 Tahun 2007 Tentang Pengelolaan Wilayah Pesisir dan Pulau-Pulau Kecil. Pemanfaatan pulau oleh individu tidak bisa langsung diberikan hak milik, hak guna bangunan, hak guna usaha, sehingga harus ada permintaan ijin pemanfaatan pulau-pulau kecil dan perairan sekitarnya. Pulau kecil dikuasai oleh negara, kemudian negara mengatur penguasaannya dalam bentuk perijian kepada pihak lain baik itu perseorangan atau swasta.

Terkait ijin pemanfaatan pulau, ditilik kembali lokasi dan posisi pulau tersebut. Apabila berada di pulau terluar dan perairan maka ijin pengelolaan diberikan oleh 
Kementerian Kelautan dan Perikanan, sedangkan pada wilayah daratan pulau maka kewenangannya ada pada masing-masing Bupati dan Walikota setempat. Peraturan Menteri Kelautan dan Perikanan No. 54/PERMEN-KP/2020 tentang Ijin Lokasi, Ijin Pengelolaan dan Ijin Lokasi di Laut menjelaskan ijin terkait pengelolaan dan pemanfaatan sumber daya perairan pulau-pulau kecil untuk kegiatan :

a. Produksi garam;

b. Wisata Bahari

c. Pemanfaatan air laut selain energy;

d. Pengusahaan Pariwisata Alam perairan di Kawasan Konservasi;

e. Pengangkatan benda muatan Kapal tenggelam;

f. Biofarmakologi Laut, dan

g. Bioteknnologi Laut.

Sedangkan penggunaan dan pemanfaatan tanah di pulau-pulau kecil dapat dicatat dalam buku tanah dan sertifikat. Dalam hal pulau-pulau kecil belum terdapat penguasaan tanah, maka penguasaannya diprioritaskan untuk Pemerintah pusat. Pemerintah dapat menguasai dan memanfaatkan pulau-pulau Kecil secara utuh jika diperlukan untuk kepentingan nasional. Hak Atas Tanah dapat diberikan kepada pulau-pulau kecil dengan syarat-syarat tertentu yang harus dipenuhi dan dengan tidak menutup akses publik terhadap pulau tersebut. Pengaturan terhadap pulaupulau kecil di seluruh wilayah Indonesia telah diatur secara lebih eksplisit dalam Peraturan Menteri Agraria No. 17 Tahun 2016 (Permen Agraria 17/2016). Pemberian hak atas tanah di pulau-pulau kecil sebagaimana telah diatur dalam pasal 9 ayat (2) Permen Agraria 17/2016, harus memperhatikan hal-hal sebagai berikut:

a. Sesuai dengan petunjuk rencana tata ruang wilayah provinsi/kabupaten/kota dan/atau rencana zonasi pulau kecil tersebut, Penguasaan atas pulau-pulau kecil paling banyak 70\% (tujuh puluh persen) dari luas pulau;

b. Wilayah pulau-pulau kecil yang ada dikuasai langsung oleh negara dan digunakan untuk kawasan lindung, pemanfaatan dan pemanfaatan kawasan umum atau kemanfaatan masyarakat paling sedikit tersisa 30\% (tiga puluh persen); dan

c. Untuk kawasan hutan lindung, harus mengalokasikan 30\% (tiga puluh persen) dari luas pulau. 
Mengenai penguasaan dan kepemilikan pulau-pulau kecil tersebut, tidak boleh menutup akses publik yang mana akses ini terkait dengan akses perorangan maupun kelompok untuk berteduh, berlindung serta menyelamatkan diri dan mencari pertolongan dalam pelayaran. Untuk dapat melaksanakan kegiatan yang berkaitan dengan penelitian, pendidikan, serta konservasi alam harus mendapat ijin secara resmi dari isntansi terkait. Selain syarat yang diatur dalam peraturan perundangundangan, pemberian Hak Atas Tanah di pulau-pulau kecil juga harus memenuhi syarat sesuai dengan pasal 11 ayat (2) Permen Agraria 17/2016 antara lain:

a. Peruntukannya sesuai dengan rencana tata ruang wilayah provinsi/kabupaten/kota, atau rencana zonasi Pulau-Pulau Kecil;

b. Mendapat rekomendasi dari pemerintah provinsi/kabupaten/kota dalam hal belum diatur mengenai peruntukan tanah dalam Rencana Tata Ruang Wilayah (RTRW); dan

c. Memenuhi ketentuan perizinan dari instansi terkait.

Mengenai tanggung jawab atas terjadinya jual beli pulau lantigiang, dapat ditinjau kembali terkait pemberian ijin pemanfaatan lahan di pulau tersebut. Sebagaimana pengakuan dari si penjual pulau, bahwa tanah di pulau tersebut telah dimanfaatkan secara turun temurun dengan ditanami pohon kelapa dan tidak mengetahui bahwa pulau tersebut termasuk kawasan yang dilindungi. Mengenai status tanah di pulau lantigiang yang telah diatur dalam SK Menteri Kehutanan Nomor 92/KPTS-II/2001 tanggal 15 Maret 2001 yang menetapkan bahwa pulau lantigiang termasuk dalam kawasan Taman Nasional Takabonerate yang tidak dapat diperjualbelikan. Oleh sebab itu pengaturan pengelolaan lahan di pulau lantigiang mengacu pada Undang-Undang No. 1 tahun 2014 tentang Perubahan atas UndangUndang Nomor 27 Tahun 2007 Tentang Pengelolaan Wilayah Pesisir dan PulauPulau Kecil. Berdasarkan Asas fiksi hukum, sebagaimana yang tercantum dalam penjelasan pasal 81 Undang-Undang Nomor 12 Tahun 2011 tentang Peraturan Perundang-undangan yakni "Dengan diundangkannya Peraturan Perundangundangan dalam lembaran resmi sebagaimana dimaksud dalam ketentuan ini, setiap orang dianggap telah mengetahuinya" (presumption iures de iure). Sehingga tidak ada satupun dalih yang membenarkan bahwa pelaksanaan jual beli tersebut terjadi karena penjual tidak mengetahui bahwa tanah di pulau tersebut merupakan kawasan 
yang dilindungi. Ketidak tahuan seseorang atas hukum tidak dapat membebaskannya dari segala tuntutan hukum (Ignorantia Jurist Non Excusat).

\section{KESIMPULAN}

Perjanjian Jual Beli pada dasarnya harus memenuhi syarat-syarat jual beli menurut pasal 1320 KUH Perdata. Syarat tersebut terdiri dari 4 (empat) yang harus dipenuhi antara lain : Pertama, Adanya kata sepakat bagi mereka yang mengikatkan dirinya; Kedua, Kecakapan para pihak untuk membuat suatu perikatan; Ketiga, Suatu hal tertentu; dan Keempat, Suatu sebab (causa) yang halal. Dalam jual beli yang berlangsung, apabila syarat pertama yaitu kata sepakat dan syarat kedua yaitu kecakapan para pihak tidak dapat terpenuhi maka perjanjian tersebut dapat dibatalkan. Batalnya suatu perjanjian harus diajukan oleh salah satu pihak yang melakukan perjanjian. Sedangkan batal demi hukum mengandung maksud bahwa suatu perjanjian dianggap tidak sah dan tidak pernah ada/tidak pernah terjadi. Pulau Lantigiang sebagai obyek perjanjian jual beli berstatus sebagai tanah konservasi yang termasuk dalam zona pemanfaatan Taman Nasional Takabonerate. Obyek perjanjian tersebut dianggap tidak sah menjadi obyek suatu perjanjian jual beli karena wilayah yang termasuk tanah konservasi tidak dapat diperjual belikan. Oleh sebab itu, perjanjian jual beli yang terjadi antara Syamsul Alam dengan Asdianti dengan obyek jual beli yaitu tanah di Pulau Lantigiang, dianggap tidak sah dan tidak pernah ada karena melanggar syarat obyektif dari syarat sahnya perjanjian berdasarkan pasal 1320 KUH Perdata.

Negara sebagai pemegang kekuasaan yang diamanatkan dalam pasal 33 ayat (2) UUD 1945 mengatur seluruh kekayaan alam yang ada di wilayah Negara Indonesia. Amanat ini diwujudkan dalam hak menguasai oleh Negara, di dalam hak tersebut negara memberikan kekuasaan kepada yang mempuyai hak untuk menggunakan hak nya sehingga dalam hal ini Negara selaku organisasi kekuasaan seluruh rakyat bertindak sebagai kuasa dari Bangsa Indonesia. Sebagai kuasa dari rakyat pemegag hak, maka sudah sepatutnyalah Negara yang dalam hal ini Pemerintah Daerah sebagai wakil dari Pemerintah Pusat di daerah turut bertanggungjawab atas terjadinya praktek jual beli pulau lantigiang. Pulau Lantigiang masuk dalam wilayah Kepulauan Selayar Provinsi Sulawesi Selatan sehingga yang 
patut bertanggung jawab adalah Pemerintah Daerah Kepulauan Selayar dan Pemerintah Provinsi Sulawesi Selatan. Melalui beragam Peraturan Daerah dan Pusat yang mengatur adanya wilayah konservasi Taman Nasional menjadikan tanggungjawab sepenuhnya dari Pemerintah Daerah untuk dapat melindungi wilayah tersebut.

\section{DAFTAR PUSTAKA}

\section{Buku}

Aminuddin Ilmar, Hak Menguasai Negara Dalam Privatisasi BUMN, Kencana Prenada Media Group, Jakarta, 2012.

Boedi Harsono, Sejarah Pembentukan Undang-undang pokok Agraria, Isi dan Pelaksanaannya, Djambatan, Jakarta, 1999.

Much. Nurachmad, Buku Pintar Memahami dan Membuat Surat Perjanjian, Transmedia Pustaka, Jakarta, 2010.

Peter Mahmud Marzuki, Penelitian Hukum (Edisi Revisi), Kencana, Jakarta, 2017.

Soerjono Soekanto, Pengantar Penelitian Hukum Indonesia, Universitas Indonesia, Jakarta, 1981.

Sudikno Mertokusumo, Ilmu Hukum, Penerbit Liberty, Yogyakarta, 2008.

Urip Santoso, Pendaftaran dan Peralihan Hak Atas Tanah, Kencana Prenada Media, Jakarta, 2009.

\section{Artikel Ilmiah}

Retna Gumanti, Syarat Sahnya Perjanjian (Ditinjau dari KUHPerdata), Jurnal Pelangi $\begin{array}{llll}\text { Ilmu, } & \text { Volume } & 5 & \text { No. }\end{array}$ http://ejurnal.ung.ac.id/index.php/JPI/article/view/900/840\#, 2012 .

Nanin Koeswidi Astuti, Analisa Yuridis tentang Perjanjian Dinyatakan Batal Demi Hukum, Jurnal Hukum to-ra, Volume 2 No. 1, http://ejournal.uki.ac.id/index.php/tora/article/view/1130/958, April 2016

\section{Internet}

https://ditjenbinaadwil.kemendagri.go.id/index.php/2020/09/01/koordinasipenyamaan-persepsi-jumlah-pulau-di-indonesia-tahun-2020/ diakses 16 Maret 2021.

https://databoks.katadata.co.id/datapublish/2016/ diakses 16 Maret 2021. 
https://www.liputan6.com/regional/read/4472400/klaim-sebagai-peninggalannenek-moyangnya-warga-selayar-jual-pulau-lantigiang-seharga-rp900-juta diakses tanggal 18 Maret 2021.

https://id.wikipedia.org/wiki/Taman Nasional Taka Bonerate diakses tanggal 19 Maret 2021.

\section{Peraturan Perundang-undangan}

Undang-Undang No. 5 Tahun 1960 tentang Peraturan Dasar Pokok-Pokok Agraria.

Undang-Undang Nomor 5 Tahun 1990 tentang Konservasi Sumber Daya Alam Hayati dan Ekosistemnya.

Undang-Undang Nomor 12 Tahun 2011 tentang Peraturan Perundang-undangan.

Undang-Undang No. 1 tahun 2014 tentang Perubahan atas Undang-Undang Nomor 27 Tahun 2007 Tentang Pengelolaan Wilayah Pesisir dan Pulau-Pulau Kecil.

Peraturan Menteri Agraria No. 17 Tahun 2016 tentang Penataan Pertanahan Di Wilayah Pesisir dan Pulau-Pulau Kecil.

Peraturan Pemerintah No. 18 tahun 2021 (PP 18/2021) tentang Hak Pengelolaan, Hak Atas Tanah, Satuan Rumah Susun, dan Pendaftaran Tanah.

Keputusan Direktorat Jenderal PHKA Nomor : SK. 150/IV-SET/2012 tanggal 17 September 2012 tentang Zonasi Taman Nasional Taka Bonerate.

Surat Keputusan Direktorat Jenderal Konservasi Sumber Daya Alam dan Ekosistem Nomor : SK.23/KSDAE/SET/KSA.0/1/2019.

SK Menteri Kehutanan Nomor 92/KPTS-II/2001 tanggal 15 Maret 2001 